
\title{
$\begin{array}{ll}\text { Research Square } & \begin{array}{l}\text { Preprints are preliminary reports that have not undergone peer review. } \\ \text { They should not be considered conclusive, used to inform clinical practice, } \\ \text { or referenced by the media as validated information. }\end{array}\end{array}$
}

\section{Environmental implications of fluoride presence in drinking water along the southeastern of El Bajío Guanajuatese, Guanajuato, Mexico: sources and health effects}

José Iván Morales Arredondo ( $\nabla$ ivanma@geofisica.unam.mx )

Universidad Nacional Autonoma de Mexico Instituto de Geofisica https://orcid.org/0000-0002-7529-992X

Armienta Hemández

Universidad Nacional Autonoma de Mexico Instituto de Geofisica

I.Z. Flores-Ocampo

Instituto de Ciencias del Mar y Limnología: Universidad Nacional Autonoma de Mexico Instituto de Ciencias del Mar y Limnologia

R. Flores-Vargas

Universidad Nacional Autonoma de Mexico Instituto de Geologia

\section{Research Article}

Keywords: fluoride mobilization, groundwater, volcanic rocks, geothermal aquifer, fluoride exposure risk

Posted Date: January 13th, 2022

DOI: https://doi.org/10.21203/rs.3.rs-1209504/v1

License: () (1) This work is licensed under a Creative Commons Attribution 4.0 International License. Read Full License 


\section{Abstract}

Chronic exposure from drinking water with naturally high concentrations of fluoride (F区) has serious health consequences in several regions across the world including north-central Mexico as Guanajuato State, where the rural population is particularly dependent on untreated groundwater pumped from wells that have natural F- concentrations higher than those allowed by national and international regulations. The contaminated aquifers in the area are usually located in fractured volcanic environment that interacts with sedimentary basins and have a carbonate basement. Few studies focused on identifying the origin and hydrogeochemical processes related to fluoride release and mobilization have been developed, and even fewer that quantify the natural content of $F$ in the geological environment. In this study, an evaluation of fluoride in volcanic rocks collected from 11 sampling sites along the Sierra de Codornices (Guanajuato State, Central Mexico) was carried out. The fluoride content is disseminated in volcanic rocks and the highest contents were obtained in felsic rocks. According to results obtained of a sampling campaign of 32 wells in 2019 their statistical and hydrogeochemical evaluation suggest that F- mobilization in groundwater from Juventino Rosas and Villagran municipalities, is a product of volcanic glass dissolution, a process involved in alkaline desorption occurring on the surfaces of F-containing minerals, and possibly on ion exchange occurring in minerals and some clays or even in deep fluids enriched in F. All these processes may be accelerated by the geothermal characteristics of the groundwater in the study area. The hydrogeochemical results and the epidemiological survey conducted indicate that children and older adults of Praderas de la Venta are at risk of exposure to F- due to the high concentrations ingested over a long period of time, to the toxicity of the element and its ability to accumulate in the bones. Prolonged exposure to high concentrations increases the risk.

\section{Introduction}

Worldwide, the presence of fluoride $\left(\mathrm{F}^{-}\right)$in high concentrations in groundwater is a serious epidemiological problem related to their exposure and intake (Armienta et al., 2008). Several countries in Europe, Africa, and Asia have reported critical health situations at the population level (Smedley and Kinninburg, 2002, Jiménez-Zabala et al., 2017; Onipe et al., 2020). The main intake of $F^{-}$for humans is through food and beverage (ATSDR, 2016), ingestion of $F^{-}$by consumption of contaminated water is a recurrent mode of exposure in some populations in the country (Jiménez-Zabala et al., 2017). Other routes of exposure are accidental ingestion of fluorideenriched soils and the use of chemicals, which enter the body by direct ingestion or inhalation (ATSDR, 2016). Ingestion of $\mathrm{F}^{-}$causes dental fluorosis and, in some severe cases, skeletal fluorosis. A correlation has also been observed between fluoride concentration and low IQ and lung cancer in people working in F-related industries (Rocha-Amador et al., 2007; Liu and Qian, 2008; Tang, 2008; Li, 2003; Chiba et al.; 2002; Strunecká and Patočka, 2002).

The presence of $\mathrm{F}^{-}$in natural water is related to the abundance, solubility and reaction kinetics of minerals and rocks inaquifers, where temperature affects its release (Selinus 2005; Armienta et al., 2008; Onipe et al., 2020). Elevated fluoride content in groundwater is commonly found in regions with preferentially felsic volcanic history (silicic granites), in sedimentary basins located in arid areas or in geothermal environments (Abu Rukah and Alsokhny, 2004; De Rita et al., 2011; Edmund and Smedley 2013). Fluoride is released to the medium naturally in a manner like dehydroxylation (although the release is not stoichiometric) (Zhang et al., 2003; Zhang et al., 2013; Nicolli, 2012; Barranquero et al., 2017), product of weathering and dissolution of minerals, although its presence can also increase product of volcanic emissions or marine aerosols. Factors controlling the concentration of fluoride in groundwater are geology, depth, salinity, temperature, pH, porosity, and water-rock interaction time (Gi-Tak et al., 2006; Chae et al., 2007; Nicolli, 2012; Savoie, 2013). The solubility of Fis low in aqueous solutions due to a high electronegativity that predisposes its combination with other elements present in the water, it also has a high ionization energy (Johannesson and Tang, 2009). The mobility of $\mathrm{F}^{-}$increases under high temperature conditions, this volatile element is found in hydrothermal solutions along with boron and in smaller proportion with chlorine, the dissolution reaction time of the minerals present in the aquifers, mainly of igneous origin, controls the concentration of fluoride in the water (Sung, 2011), although evaporite deposits in arid conditions can be an important source, high concentration of fluorides can occur in groundwater that have had a longer residence time, probably as a result of diagenetic processes. The concentration of $\mathrm{F}^{-}$ranges in groundwater between 1 and $25 \mathrm{mg} / \mathrm{L}$ although in some cases it is higher (Clark, 2015). Fluoride concentrations in water in arid climatic conditions are high, due to slow infiltration flow while in humid tropical environments are usually low due to high rainfall and groundwater dilution effects (Edmunds and Smedley, 2013). Surface waters typically have low $\mathrm{F}^{-}$concentrations, it has been observed that the usual ranges of $\mathrm{F}^{-}$are between $0.01-0.3$ (mg/L), similarly to recently infiltrated water and rainwater, an exception occurs in areas with volcanic activity where shallow waters are affected by hydrothermal fluids (Guo et al., 2007; Deng et al., 2011; Morales-Arredondo et al., 2020a; Moran-Ramírez et a., 2020).

Groundwaters with high fluoride values, have a predominant composition of $\mathrm{Na}$ and $\mathrm{HCO}_{3}{ }^{-}$and low $\mathrm{Ca}^{2+}$ concentration and pH values between 7 and 9 , mainly where cation exchange between Ca-Na has occurred, calcic aquifers have low $\mathrm{F}^{-}$concentrations (Guo et al., 2007), high $\mathrm{F}^{-}$concentrations and alkaline $\mathrm{pH}$ correspond to a silica increase (Savoie, 2013; Onipe et al., 2020). Speciation strongly depends on $\mathrm{pH}$, in acidic conditions it can form complexes with $\mathrm{H}+$ and $\mathrm{Al} 3+$, at pH 3.5 the dominant species is $\mathrm{HF}^{\circ} . \mathrm{F}^{-}$is the dominant form in natural waters, besides, it can form complexes with major cations such as Ca, Na and $\mathrm{Mg}$ (Deng et al., 2011) and minor species as B, Be, V, U, $\mathrm{Fe}^{3+}$ and Si that can enhance fluoride mobilization if they are present in solution in significant amount. Mineral dissolution, ion exchange in micas and clay alteration are the main causes of $\mathrm{F}^{-}$enrichment in groundwater.

In various regions of the America water for human consumption has high concentrations of $\mathrm{F}^{-}$. Countries such as Argentina, Canada, Chile, Cuba, El Salvador, United States, Mexico, Nicaragua, among others, have reported fluoride contamination in drinking water (Armienta et al., 2008, Armienta et al., 2010), which is linked to the geological and tectonic characteristics of each site, particularly in Central America, a place with significant tectonic and volcanic activity. In Mexico, the existence of this contaminant has been widely reported. Some examples of $\mathrm{F}^{-}$contamination have been seen in Zimapán Hidalgo, Durango, Coahuila, San Luis Potosí, Guanajuato, among others. Groundwater contamination is one of the main problems in the water supply policies faced by Mexico and the world, since it is a determining factor that is linked to public health. In Juventino Rosas (JR), it has been observed that the presence of $\mathrm{F}^{-}$in the aquifer that supplies the the municipality represents a risk to the health of the population (Morales-Arredondo et al., 2018a, 2018b, 2020). This problem has led us to carry out this study including the characterization of the water extracted from different wells, in addition to determining sources and routes of $\mathrm{F}^{-}$exposure. 
Ann exhaustive study must be carried out to determine the physical, chemical and geological factors that govern the aquifer, such as the type of rocks through which the water flows, porosity, $\mathrm{pH}$, temperature and depth, the redox (Eh) conditions and the solubility characteristics of some minerals present at the site, as well as the oxidation-reduction processes occurring in that environment, and high F-containing minerals that can lead to high groundwater fluoride concentrations (Edmunds and Smedley, 2013; Armienta et al., 2010).

The objective of this work was to quantify the $\mathrm{F}$ content in different volcanic rocks present in the study area, identify how $\mathrm{F}$ is distributed in the aquifer minerals, define the processes that cause the release of $\mathrm{F}^{-}$in groundwater and estimate the risk of exposure of the population living in the region. This work shows that after the emission of volcanic material there is an accumulation of fluorine in the glassy matrix of various volcanic rocks in the area and that, due to devitrification processes and the presence of geothermal areas, the release of $\mathrm{F}^{-}$into groundwater increases. In addition, in the study region there is evidence that this element has been present for at least 10 years in the drinking water of several communities, which represents a risk to the population.

\section{Background}

\section{Location and social context of the municipalities of Juventino Rosas and Villagrán, Guanajuato}

The municipalities of Villagrán (Vill) and Santa Cruz de Juventino Rosas (JR) are located in the Transmontane Volcanic Belt; to the north, the Sierra de Guanajuato limits the valley, to the south the Lerma River limits the area, both municipalities belong to the western portion of the Celaya Valley Aquifer (AVC), in the southern area of the State of Guanajuato (Figure 1). Livestock and agriculture are the basis of the regional economy, both activities intensively extract groundwater as agriculture-livestock occupies between $75 \%$, domestic use occupies between $22 \%$ and industry occupies up to $3 \%$, this is the only source of water for human consumption in the region (INEGI 2017). According to reports from the Institute of Ecology of the State of Guanajuato (IEEG 2008) in the area agricultural activity has increased up to three times in the last 48 years, this situation has caused an imbalance between abstraction-recharge of groundwater, which translates into a severe problem of excessive extraction (Rodríguez and Rodríguez-Velázquez, 2006; Rodríguez et al., 2015), the average descent of the water table varies between 1 and $2 \mathrm{~m}$ per year throughout the region. The Lerma River is the main surface water body, however, since it receives untreated urban and industrial wastewater, the main source of drinking water supply is groundwater (Schoeder, 2010).

According to the CONEVAL report (2018a and b), in both municipalities there are more than 120 thousand inhabitants, approximately $51 \%$ are women; about half of the population presents a degree of vulnerability due to social deprivation and about $40 \%$ of the population presents a degree of poverty, this situation causes the population to work from the age of 12 (more than $40 \%$ ). The average level of schooling of the population is approximately seven years and households are made up of approximately four people. $15 \%$ of the population lives in houses with poor quality materials and in small spaces, between 18 and $35 \%$ of the population in Vill and JR respectively do not have basic services in their homes (between 6.5 and $8.2 \%$ of both municipalities do not have piped water and $4.5 \%$ and $14.3 \%$ of homes do not have drainage respectively), in the entire area there are only three wastewater treatment plants located in JR (INEGI, 2017).

Figure 1

Geological and hydrogeological context of the municipalities of Juventino Rosas and Villagrán, Guanajuato.

The study area belongs to the hydrogeological province of the Celaya Valley Aquifer (Fig. 1). The basement is composed of limestones, limestones with lowgrade metamorphism, sandstones, shales and schists (Kss) (Paleozoic-Mesozoic) (Cerca-Martínez et al., 2000; Morales-Arredondo et al., 2018a; JuárezAparicio, 2019), these units' outcrop in the locality of Rincón de Centeno. To the north, the Sierra de Guanajuato, composed mainly of rhyolitic-ignimbritic rocks (Tom and Tvr), which originate from early Oligocene to late Mesozoic felsic-calcoalkaline volcanic emissions (Dahlkamp, 2010; Christiansen, 1986; ArandaGómez 1998), and Pliocene-Pleistocene basaltic rocks and andesites (Tmb and Tmo, e.g., La Ordeña andesite) (Cerca-Martínez et al. 2000; Nieto Samaniego et al., 2012) limit the study area. To the south, there are monogenetic volcanoes extending into the Michoacán-Guanajuato Field (composed of basaltic rocks), and this region is also part of the Trans-Mexican Volcanic Belt. Ignimbrites (Tom) cover much of the study area, and the basaltic plateau (Tmb) and andesitic rocks are the youngest geologic units (Nieto Samaniego et al., 2012; del Río-Varela et al., 2020).

Juventino Rosas groundwater is influenced by a geologic setting containing volcanic rocks of both acidic and basic composition and by a sedimentary basin filled with sediments of lacustrine-alluvial (Qal) origin (Morales-Arredondo et al., 2018a). The sedimentary deposits consist of conglomerates, clays, sandstones and gravels. Finally, the structural fractures present in this area have a mainly NW-SE, and NE-SW orientation (Fig. 1) (Nieto-Samaniego et al., 2012; Morales et al., 2018b; del Río-Varela et al., 2020).

The hydrogeological framework of the area is mainly composed of two aquifer units from which water is pumped. The water receives no treatment after extraction and is distributed directly to households through urban wells, which are controlled by a Municipal Water Board and a Municipal Water Commission of Vill and JR respectively (CMAPAJ, JUMAPAV). The first aquifer is hosted in granular material (irregular alternation of grain size from very fine to coarse) interspersed with fractured basalts, this is located at a depth between 50 and $150 \mathrm{~m}$, it is not confined, its average temperature is $24^{\circ} \mathrm{C}$, an important number of wells excessively extract water from this aquifer with an average flow of $40 \mathrm{~L} / \mathrm{s}$. the formation of faults and fractures in the area is related to these processes. This context has led to the closure of wells and the need to drill deeper (up to $350 \mathrm{~m}$ ) to extract water (Schoeder, 2010). The second aquifer is hosted in fractured volcanic rocks, has a depth of 200 and $350 \mathrm{~m}$, the deep water has geothermal characteristics of low temperature and high concentration of fluoride $\left(\mathrm{F}^{-}\right)$and in some cases along with arsenic (As) as established by the Mexican Drinking Water Standard (NOM-127), its temperature ranges between 29 and $50^{\circ} \mathrm{C}$. This aquifer has become the most exploited unit in recent years (with an average flow of $45 \mathrm{~L} / \mathrm{s}$ ), due to the depletion of the superficial one, a situation that could be related to its poor quality for human consumption (Morales-Arredondo et al., 2018a and b). 


\section{Methodology}

\section{Rock sampling, chemical and mineralogical analysis.}

To characterize the rock samples, a mineralogical evaluation was performed at the Laboratorio de Difracción de Rayos X of the Institute of Geology, Universidad Nacional Autónoma de México (UNAM), using X-ray diffraction (XRD) with an EMPYREAN diffractometer equipped with a nickel (Ni) filter, fine focus copper tube, and PIXcel3D detector, the diffractograms were obtained in the $2-\theta$ angular interval from $5^{\circ}$ to $70^{\circ}$ using a "step scan" with a $0.003^{\circ}(2-\theta)$ step and an integration time of 40 seconds per step for limestone rocks, and at the National Laboratory of Geochemistry and Mineralogy with a diffractometer TERRA, Olympus for volcanic rocks; a minimum of $2 \mathrm{~g}$ of sample previously pulverized and sieved through a 100 mesh sieve, i.e. to a particle size $\leq 149 \mu \mathrm{m}$, was required for the analysis. The signals emitted by a cobalt radiation source on the fine powder were diffracted after an angular interval of $5^{\circ}$ to $55^{\circ}$, with a minimum scanning of 50 exposures, the mineralogy showed in the diffractograms was identified with the help of X Powder Ver. 2010.01 .35 PRO software with a PDF2 database.

Mineralogical analysis was carried out, wherein rock samples were examined with an optical microscope. In addition, a petrographic study was performed to identify the dominant minerals and their textural phases as well as their relationships. The following equipment was used for these latter analyses: a polarized optical microscope with transmitted and reflected light (Carl Zeiss, Axiolab Pol) fitted with an image analysis system (KS300), a stereomicroscope (Zeiss 475022), and a petrographic microscope (Leica, MD LP). During the evaluation with the optical microscope, both transmitted and reflected light were used to identify opaque and translucent minerals. Mineralogical analysis was also performed through optical microscopy and scanning electron microscopy with energy-dispersive X-ray spectroscopy (SEM-EDS) using a JEOL microprobe at the Laboratorio de Petrología, UNAM. Elemental compositional mapping was obtained with energy-dispersive X-ray spectroscopy (EDS) analyses.

\section{Quantification of fluorine content in rocks through alkaline fusion.}

The F content in volcanic rocks from the southeastern Sierra de Guanajuato was determined based on the alkaline fusion method proposed by Shimizu et al. 2006. The method was modified to quantify the fluorine content in 11 volcanic rocks of different classifications, using a selective electrode after extraction by alkaline fusion. The powdered sample was mixed with sodium carbonate and potassium carbonate in a mass ratio of 5:11:14, placed in a platinum crucible and melted in an electric furnace at $1100{ }^{\circ} \mathrm{C}$ for 25 minutes. The crucible was removed from the muffle and placed on ice to lower the temperature and solidify the molten mixture.

Inside a vial, a few drops of $10 \%$ hydrochloric acid were poured over the walls to loosen the paste formed inside and with the help of a spatula, pressure was exerted to break the paste into small pieces so that it could be transferred to a centrifuge tube. The crucible was rinsed with deionized water to remove as much residue as possible from the tube. Each set of fragments previously obtained by alkaline fusion was poured into a beaker, $50 \%$ hydrochloric acid was added to dissolve the carbonates and also bring the mixture to a neutral pH. When a neutral pH was obtained (measured with an Expandable ion Analyzer EA 940 multiparameter), the contents of the beaker were transferred to a $25 \mathrm{~mL}$ volumetric flask with distilled water. Subsequently, the solid was precipitated, the mixture was centrifuged for 5 minutes and the supernatant liquid was deposited in the original beaker, the liquid was agitated with a magnetic bar and the $\mathrm{pH}$ of the liquid was measured in all the samples during this process, resulting alkaline, for which it was neutralized again with $10 \%$ hydrochloric acid (taking it to a capacity of $30 \mathrm{~mL})$.

To measure F concentrations, a potentiometer with selective electrode was used, once the neutral value was reached, implementing the Thermo Scientific Orion 5 Star selective electrode technique, established in the Analytical Chemistry Laboratory of the Geophysics Laboratory of the UNAM, using standard additions. A TISAB solution was added to the standards and samples to adjust the ionic strength and avoid the formation of complexes (Table 1 and 2 ). The "Thermo scientific Orion 5 star" has a fluoride ion selective electrode with a working range from 0.1 to $10 \mathrm{mg} / \mathrm{L}$, some samples had thus to be diluted by a factor of (5:1 and 10:1) and others were analyzed directly to fall within this range. We also report fluoride contents in two reference materials, including granite (G2), and andesite (AGV-1), peridotite (PCC-1). The fluoride contents in the reference materials in this study were consistent with previously reported values. The results obtained by subjecting the PCC-1 and G2 standards to the same alkaline selective electrode melting methodology reflect a recovery percentage of 75 and $82 \%$ respectively according to the concentrations reported by Flanagan 1976 and Jochun et al., 2015 for both standards. 
Table 1

Mineralogical composition of the volcanic rocks sampled and analyzed by XRD, and average concentration of fluorine and arse X-Ray Diffraction (\%)

\begin{tabular}{|c|c|c|c|c|c|c|c|c|c|c|c|c|}
\hline Sample & $\begin{array}{l}\text { Rock } \\
\text { type }\end{array}$ & Quartz & Cristobalite & Tridimite & $\begin{array}{l}\text { Feldspar } \\
\mathrm{Na}-\mathrm{Ca}\end{array}$ & Sanidine & Andesine & $\begin{array}{l}\text { Plagioclase } \\
\text { albite }\end{array}$ & Monoalbite & Alunite & kaolinite & $\begin{array}{l}\text { Kaolini } \\
\text { montm }\end{array}$ \\
\hline JR-01 & Dacite & 3 & 0 & 14.3 & 0 & 17.8 & 43.7 & 0 & 0 & 0 & 0 & 0 \\
\hline JR-02 & Dacite & 8.9 & 0 & 9.9 & 0 & 19.4 & 42.8 & 0 & 0 & 0 & 0 & 0 \\
\hline JR-03 & $\begin{array}{l}\text { Basalt- } \\
\text { Andesite }\end{array}$ & 2.8 & 0 & 0 & 0 & 18.3 & 78.4 & 0 & 0 & 0 & 0 & 0 \\
\hline JR04 & Andesite & 2.5 & 0 & 0 & 0 & 23.6 & 73.9 & 0 & 0 & 0 & 0 & 0 \\
\hline JR-06 & $\begin{array}{l}\text { Quartz- } \\
\text { alunite }\end{array}$ & 4.5 & 0 & 25.9 & 0 & 0 & 0 & 0 & 0 & 35 & 0 & 13.8 \\
\hline JR-07 & Rhyolite & 4.1 & 4.3 & 13.4 & 33.3 & 0 & 0 & 0 & 13 & 0 & 9.6 & 0 \\
\hline JR-08 & Basalt & 1.1 & 4.5 & 1.3 & 0 & 0 & 41.4 & 0 & 0 & 0 & 0 & 22.2 \\
\hline JR-09 & Rhyolite & 17.6 & 4.7 & 3.9 & 0 & 16.4 & 0 & 27.2 & 0 & 0 & 0 & 12.9 \\
\hline JR-10 & $\begin{array}{l}\text { Basalt- } \\
\text { Andesite }\end{array}$ & 2.1 & 0 & 0 & 0 & 15.3 & 60.7 & 0 & 0 & 0 & 0 & 0 \\
\hline JR-11 & $\begin{array}{l}\text { Basalt- } \\
\text { Andesite }\end{array}$ & 1.1 & 0 & 0 & 0 & 6.7 & 61.5 & 0 & 0 & 0 & 0 & 0 \\
\hline
\end{tabular}

Table 2

Summary of physicochemical and isotopic results of groundwater samples from the stt

\begin{tabular}{|c|c|c|c|c|c|c|c|c|c|c|c|c|c|c|}
\hline Well 2019 & $\begin{array}{l}\mathrm{T} \\
\left({ }^{\circ} \mathrm{C}\right)\end{array}$ & $\begin{array}{l}\text { C.E. } \\
(\mu S / \mathrm{cm}) \\
2019\end{array}$ & $\mathrm{pH}$ & $\begin{array}{l}\text { depth } \\
\text { (m) }\end{array}$ & $\begin{array}{l}\text { Eh } \\
(V)\end{array}$ & $\begin{array}{l}\mathrm{Na} \\
(\mathrm{mg} / \mathrm{L})\end{array}$ & $\begin{array}{l}\mathrm{Mg} \\
(\mathrm{mg} / \mathrm{L})\end{array}$ & $\begin{array}{l}\mathrm{Ca} \\
(\mathrm{mg} / \mathrm{L})\end{array}$ & $\begin{array}{l}\mathrm{K} \\
(\mathrm{mg} / \mathrm{L})\end{array}$ & $\begin{array}{l}\mathrm{Cl} \\
(\mathrm{mg} / \mathrm{l})\end{array}$ & $\begin{array}{l}\mathrm{SO} 4 \\
(\mathrm{mg} / \mathrm{l})\end{array}$ & $\begin{array}{l}\mathrm{HCO} 3 \\
(\mathrm{mg} / \mathrm{l})\end{array}$ & $\begin{array}{l}\text { NO3 } \\
\text { (mg/L) }\end{array}$ & $\begin{array}{l}\text { B } \\
(\mathrm{mg} / \mathrm{L})\end{array}$ \\
\hline minimum & 23.40 & 427.00 & 6.67 & 100.00 & 0.14 & 22.51 & 1.38 & 4.57 & 2.64 & 2.46 & 7.36 & 213.00 & 0.56 & 0.10 \\
\hline maximum & 51.28 & 1313.00 & 8.19 & 520.00 & 0.33 & 155.00 & 74.74 & 124.02 & 26.25 & 100.00 & 211.54 & 454.67 & 227.59 & 1.62 \\
\hline std desv & 7.90 & 215.01 & 0.37 & 85.93 & 0.04 & 33.49 & 14.12 & 25.45 & 6.31 & 22.32 & 47.32 & 62.05 & 45.08 & 0.35 \\
\hline $\begin{array}{l}\text { number } \\
\text { samples }\end{array}$ & 29 & 29 & 29 & 29 & 29 & 29 & 29 & 29 & 29 & 29 & 29 & 29 & 29 & 29 \\
\hline average & 33.32 & 743.76 & 7.53 & 283.96 & 0.19 & 92.14 & 11.63 & 33.50 & 11.66 & 21.70 & 50.25 & 296.78 & 24.31 & 0.35 \\
\hline
\end{tabular}

Total arsenic contents in volcanic and limestone rocks were quantified with hydride generation atomic absorption spectroscopy after acid digestion of the rock samples with a Perkin Elmer AAnalyst200 and FIAS 100 at the Laboratorio de Química Analítica of the Geophysics Institute, UNAM.

\section{Water Sampling And Chemical Analysis}

A groundwater sampling campaign was conducted in the municipalities of Villagrán (Vill) and Juventino Rosas (JR), Guanajuato in 2019 (32 wells in the dry season [April]), following the standard methods of APHA-AWWA (2005) and Mexican standards (NOM-127-SSA1 and NOM-230-SSA1). Urban and agricultural wells were included in the sampling. Temperature, $\mathrm{pH}$ and electrical conductivity were measured in the field. The equipment was calibrated to the water temperature at each site, and a PC18 conductivity meter, a HI model pH/EC/TDS/Temp meter and a Hanna model HI 9829 multiparameter equipment were used.

Chemical analyses of anions and cations were performed at the Analytical Chemistry Laboratory of the Institute of Geophysics, UNAM, Mexico. This laboratory participates in international calibration exercises (Verma et al. 2012, 2015; Stewart et al. 2020). Major ions were analyzed following standard methods (APHA-AWWA 2005). Bicarbonate was determined by volumetry (titration with $\mathrm{HCl})(\mathrm{VC}=6 \%)$, and $\mathrm{Ca}^{2+}$ and $\mathrm{Mg}^{2+}$ were determined by volumetry (tritiation with EDTA) (VC = 1\%); $\mathrm{Cl}^{-}$was determined by potentiometry with selective electrodes $(\mathrm{VC}=1 \%)\left(4500-\mathrm{Cl}^{-}\right)\left(\mathrm{APHA}^{-\mathrm{AWWA}^{2}} 2005\right)$; $\mathrm{Na}^{+}$and $\mathrm{K}^{+}$were

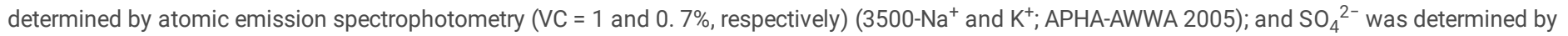
turbidimetry $(\mathrm{VC}=1 \%)$ (method $4500-\mathrm{SO}_{4}{ }^{2-}$ ). To evaluate the behavior of $\mathrm{F}^{-}$over several years, several monitoring campaigns were conducted in different urban and agricultural wells in both municipalities. Analytical determinations were performed at the Analytical Chemistry Laboratory of the Institute of Geophysics (UNAM) following APHA-AWWA (2005) analytical procedure standards. A Thermo Scientific Orion 5 Star potentiometer with selective electrode was used to measure $\mathrm{F}^{-}$concentrations. 


\section{Hierarchical Clustering}

Hierarchical clustering $(\mathrm{HC})$ is a statistical approach aimed at deriving a cluster hierarchy from a data matrix. Most clustering techniques use specific metrics that quantify the distance among pairs of elements and a linking criterion that specifies the dissimilarity of two sets of elements (clusters) as a function of the similarity (measured with an appropriate geometric distance) among elements in the two sets. The choice of an appropriate metric influences the shape of the clusters since some elements can be closer by using one distance and more distant by using another. Among the most common metrics, the Weighted pairgroup centroid (median) implemented with 1-Pearson $r$ rule has been used to derive classification trees (dendrograms) from a data matrix composed of 15 (standardized) indicators of the mineralogy that compounds 10 volcanic rocks and their As and F content in each rock. Weighted pair group method with centroid considers the similarity between two clusters equals their similarities as composite objects but determining their composite composition using only the last two objects (samples or clusters) to be joined in each cluster. Pearson's R correlation is a coefficient commonly used in linear regression. Correlation coefficient are used to find how strong a relationship is between data. Dendrograms were used to graphically assess similarity (or divergence) in the spatial distribution of a) the mineralogy and their linked with As and F content and b) the physical-chemical values, As, $\mathrm{F}^{-}$contents and isotope stable (180, $2 \mathrm{H}, 13 \mathrm{C}$ ) in groundwater. Analysis' variables were standardized prior to clustering. Indicators assuming a similar spatial pattern clustered together in the same dendrogram branch.

\section{Two-way joining}

An overall analysis was also carried out by calculating the percentage of significant correlations in total comparisons by (i) rock type ( $\mathrm{n}=10$ ); (ii) mineralogy percentage $(n=10)$. A two-joining clustering run on a data matrix constituted of pair-wise Spearman rank coefficients between building activity and contextual indicators was finally adopted with the aim of summarizing results of the correlation analysis. Two-way joining is a multivariate technique analyzing twodimensional data matrices under the assumption that both cases (rock type) and variables (mineralogy percentage) contribute to the uncovering of meaningful latent patterns. Two-way clustering produces a graph ordering cases and variables based on similarity patterns. This graph illustrates the distribution of standardized scores (with zero-average) for each case and variable using different colors. Identification of similar (positive or negative) scores for a group of variables and cases allows definition of specific clusters.

\section{Exposure Risk Estimation.}

Additionally, a survey was conducted among adolescents and adults to learn about water management in the region, the survey considered a non-probabilistic method with random routes and simple sampling where all individuals in the target population have the same probability of participation, respondents participated voluntarily in the study with consent, their information is confidential and in any case people could decline to participate in the study and the information provided here has no other purpose than observational research. The information obtained was used to determine the risk parameters related to the intake of poor-quality water and to calculate the estimate of fluoride exposure by age range in the population. Previously, an interview was conducted in 2013 where participants were asked about age, sex, use and management of water at home, and perception of water temperature, the results were reported by Morales et al. (2018a and b); as some doubts remained related to consumption levels according to the different age ranges, a survey was conducted in 2017 where questions were included to know the frequency of consumption, in addition to the individual weight of each respondent and the length of residence where they live.

With the information obtained, estimated exposure to fluoride EFE was evaluated in people living in the municipal capital of Villagrán and the town of Pradera de la Venta (Table 1, Fig. 1, and 2), using the USEPA $(1992,2010)$ methodology (Equation 1), where $\mathrm{F}^{-}$concentrations were obtained during all monitoring campaigns. In addition, a survey of consumption patterns was conducted to know the daily intake by age $\left(\mathrm{CH}_{2} \mathrm{O}\right)(\mathrm{L})$, body weight $($ Wind) $(\mathrm{kg})$, residence time (a), and household water use. This estimate was evaluated in some rural communities (Table 1, Fig. 1). For individuals surveyed in JR, standard values of population body mass and water consumption by age ranges were taken (Environment Canada 1993; Ortíz et al. 1998), while for Vill in the consumption patterns survey, body mass per person was measured and water consumption by age was asked, using the following equation for the calculations:

$\mathrm{EFE}=\left(\left[\mathrm{F}^{-}\right] \star \mathrm{CH}_{2} \mathrm{O}\right) /$ Wind $($ Eq. 1)

$\mathrm{EFE}=$ Estimated fluoride exposure ( $\mathrm{mg} / \mathrm{kg} /$ day).

$\left[\mathrm{F}^{-}\right]=$fluoride concentration in water $(\mathrm{mg} / \mathrm{L})$.

$\mathrm{CH}_{2} \mathrm{O}=$ water consumption by age (L/day).

Wind= body mass by age per individual $(\mathrm{kg})$.

The calculations considered that throughout the area the only source of drinking (and F-) water supply is from deep wells. Other routes of exposure, such as consumption of fluoridated salt, food supplements and toothpaste, were not considered, although they could be a factor to be considered later in more indepth studies.

\section{Results And Discussion}

\section{Mineralogical and geochemical characteristics of volcanic rocks from the study area}


In general, the mineralogy of the volcanic rocks obtained by DR-X shows quartz, tridymite, sanidine, andesine, cristobalite, kaolinite-montmorillonite (mainly in the dacites and rhyolites), and in some cases andesine and labradorite (in the andesites) or esseneite (in the basalt) (Table 1), in most of the samples there is the presence of amorphous material that is suggested to be volcanic glass (Figure 3, Table 1).

Table 1

This information allows inferring possible mineralogical associations and $\mathrm{F}^{-}$content, since can regularly substitute $\mathrm{OH}^{-}$in late-forming minerals in igneous rocks which facilitates its presence in various minerals formed during magmatic differentiation in late stages of magma crystallization and residual steam occurring in alkaline rocks such as siliceous granites, rhyolites or even in hydrothermal deposits, such as amphibole, biotite, mica, clay minerals and volcanic glass (De Rita et al. ., 2011; Edmunds and Smedley, 2013; Chang, 1999; Chae et al, 2006). In sediments fluorine can be present by dissolution of evaporite salts deposited in arid conditions, by biochemical reactions involving phosphorus removal. Flourine also occurs in mafic, ultramafic or ultrapotassic mantle rocks (Edgar et al, 1996; De Rita et al., 2011), in limestones containing fluorapatite (Chae et al., 2006), in topaz or fluorite (Christiansen et al., 1986; Saxena and Ahmed, 2001; De Rita et al., 2011),

Because rhyolitic rocks predominate throughout the region it is likely that the presence of $\mathrm{F}$ be linked to them; mineralogical evidence of felsic rocks show an enrichment in quartz, potassium feldspar, sanidine, sodium plagioclase, biotite, and opaque minerals (Fig. 2). These rocks in other studies show anomalous concentrations of F, S, As, and are associated with elements such as $\mathrm{Hg}$, Mo, Zr, Be, contain some lithophile incompatible elements such as $\mathrm{U}$, Be, Li, Rb, Cs $\mathrm{Nb}$, Ta W, Sn, and Th, in addition to rare earths (Dahlkamp, 2010; Christiansen 1986). The enrichment in these elements is the result of the fractional crystallization of F-rich magmas, a product of the partial melting of granulitic rocks (Aguillón-Robles et al., 1994). In the case of the study area, it has been observed that these rocks present layers of chalcedony, in some cases filled vesicles (Nava and Serna, 1958), feldspar phenocrysts, albite, orthoclase, plagioclase as oligoclase besides andesine and labradorite, quartz, microcrystalline quartz, biotite chalcedony and hornblende (Morales-Arredondo et al., 2018a and b). Rhyolitic tuffs show devitrification and alunite-kaolinite type alteration in addition to silicification. In some samples, there are montmorillonites products of hydrothermal alteration, in addition to sericites (Nava and Serna, 1958; Arellano et al., 1960; Aguillón-Robles et al., 1994; Christiansen et al., 1986).

Figure 2

\section{Two-way Joining}

This statistical method groups the information of variables and cases simultaneously, this bidirectional union allows to evaluate of significant patterns of conglomerates which share similarities. In this case the bidirectional union diagram allowed identifying and interpreting mineralogical similarities in different rock types, this information confirms felsic, intermediate and mafic mineralogical associations (Fig. 3a, Table 1). The color intensity shows the percentage of presence of each mineral in each rock, being the intense red color representative of a presence close to $62 \%$, the yellow color represents $42 \%$, while the green color represents a value of $2 \%$. The mineral with the highest presence in the different rocks is andesine, the minerals with a significant presence in the different types of rocks are sanidine, amorphous silicate tuff that is associated to the vitreous matrix and with a lower presence quartz. It is also visible that rocks JR06, JR-07, JR-08 and JR-09 are completely different from the other rocks (and even from each other), because of their mineralogical association. Rock JR-06 presents a higher presence of alunite, amorphous silicate tuff, tridymite, alteration minerals such as kaolinite-montmorillonite and a lower presence of quartz. Rock JR-07 has a higher content of Na-Ca feldspar, amorphous silicate tuff, monoalbite, tridymite, quartz, and kaolinite. Rock JR-09 has a higher content of quartz, albite-type plagioclase, sanidine, kaolinite-montmorillonite and amorphous silicate tuff. Rock JR-08 has a high content of andesine, amorphous silicate tuff, kaolinite and in smaller proportion esseneite and cristobalite.

\section{Hierarchical Clustering}

Hierarchical clustering outlines similarities and divergences in the spatial pattern of mineralogy and As and $\mathrm{F}$ contents, evidencing a correlation between As and F with Alunite and Tridimite (Figure 3b, Tabla 1). The farthest cluster (to the left) indicates a relationship between the minerals sanidine and andesine, minerals commonly found in felsic rocks, then the next cluster marks a bifurcation between esseneite and the other component minerals of volcanic rocks, but a closer relationship with Felspar $\mathrm{Na}-\mathrm{Ca}$, Monoalbite and Kaolinite these minerals are recurrent in intermediate rocks, but esseneite is common in mafic rocks, then there is a correlation between amorphous silicate tuff with two groups of minerals, on the one hand the one formed by quartz and plagioclase albite and on the other hand the one composed by kaolinite-montmorillonite with cristobalite, finally there is a cluster that indicates a correlation between tridymite with As and $\mathrm{F}$ with Alunite.

\section{Fluorine concentration in rock samples and SEM-EDS analysis.}

Several studies in the area have reported that the origin of the elevated $\mathrm{F}^{-}$concentrations in groundwater is related to the interaction between the thermal water and the volcanic rocks that constitute the aquifer (Morales-Arredondo et al, 2018a), in this work the fluoride content in the volcanic rocks of the study area is quantified (Lugo-Dorantes 2022) (Table 1); according to the results obtained, felsic rocks present the highest values of fluoride in their structure, being alunite the one with the highest $\mathrm{F}$ concentration, up to $1462.40(\mathrm{mg} / \mathrm{kg})$.

In the case of samples analyzed by scanning electron microscopy with energy dispersive X-ray spectroscopy (SEM-EDS), it is observed that fluorine is dispersed in volcanic rocks (in addition to some minerals such as hornblende, biotite and in the glassy matrix), mainly in volcanic tuff, this element is associated with devitrification and silicification in ignimbrites (Fig. 3).

Figure 4 
Hydrogeochemical behavior of groundwater samples and its relationship on F- content.

To identify processes related to $\mathrm{F}^{-}$release in groundwater, a hydrogeochemical characterization and statistical evaluation was performed with physicochemical information of groundwater sampled throughout the study area in 2019 (Table 2) and reported previously (Morales et al., 2020).

Table 2 shows the summary of chemical analysis results for 32 wells. The ionic balance for all water samples is less than $<10 \%$. Most of the groundwater in the study area is bicarbonate (except samples $\mathrm{CEN}_{2}$ ) and neutral, with a mean pH value of 7.0 (Tables 1 ). The major cations, $\mathrm{Na}^{+}, \mathrm{K}^{+}$and $\mathrm{Ca}^{2+}$ are generally dominant; $\mathrm{Mg}^{2+}$ is of secondary importance (except samples $\mathrm{CEN}_{2}$ ). Of the major anions, $\mathrm{HCO}_{3}{ }^{-}$is generally dominant; $\mathrm{SO}_{4}{ }^{2-}$ and $\mathrm{Cl}^{-}$are of secondary importance (except samples $\mathrm{CEN}_{2}$ ) (Fig. 1).

Table 2

Hierarchical Clustering

Hierarchical clustering outlines similarities and divergences in the spatial pattern of physical-chemical parameters including As and $\mathrm{F}^{-}$contents, evidencing a correlation between $\mathrm{As}$ and $\mathrm{F}^{-}$with depth, temperature and 13CVPDB (Figure 5). The farthest cluster (to the left) indicates a relationship between $\mathrm{SiO}_{2}$ and $\mathrm{B}$ contents with $\mathrm{pH}$, then the next cluster marks a bifurcation between $\mathrm{pCO}_{2}$ and Eh values with other physical-chemical and isotopic values, a closer relationship between $\mathrm{K}^{+}, \mathrm{Cl}^{-}$and $\mathrm{Na}^{+}$concentrations and E.C value is observed. Relation between stable isotopes $\left(\delta^{18} \mathrm{O}\right.$ and $\left.\delta^{2} \mathrm{H}\right)$ with $\mathrm{SO}_{4}{ }^{2-}, \mathrm{Ca}^{2+}, \mathrm{HCO}_{3}{ }^{-}$and $\mathrm{Mg}^{2+}$ contents is also shown in the dendrogram, finally, the farthest (left) branch indicates a lack of relation between $\mathrm{NO}_{3}{ }^{-}$contents and other physical-chemical parameters.

The depth factor and the residence time of the water during migration, which are related to the reaction kinetics of the aquifer minerals, are important for $\mathrm{F}^{-}$ accumulation, i.e. in some cases, high $\mathrm{F}^{-}$concentrations in groundwater are the product of long residence time (where flow rate is slow and where water-rock interaction-reaction times are long), in these arid and semi-arid regions, a positive correlation of $\mathrm{F}^{-}$with $\mathrm{pH}$ and $\mathrm{HCO}_{3}{ }^{-}$is observed (Selinus, 2005), since at $\mathrm{pH}>8 \mathrm{~F}^{-}$is mobilized from the source (Smedley et al., 2002), one of the reasons being that during migration along flow gradients a chemical response occurs during transitions leading to ion exchange and increased F- content (Abu Rukah and Alsokhny, 2004; De Rita et al., 2011; Edmund and Smedley 2013). However, these characteristics may vary in active volcanic areas, where surface and groundwater come to have hydrothermal inputs (Selinus, 2005).

Figure 5

The results of the comparative $\mathrm{Na} / \mathrm{Ca}$ vs $\mathrm{F}^{-}$ratio show that different water wells present a common increase between $\mathrm{Na}^{+}$and $\mathrm{F}^{-}$while $\mathrm{Ca}^{2+}$ decreases, in this case, two hydrogeochemical processes could explain this behavior, the alteration of plagioclase silicates (andesite-oligoclase) and micas (biotite-hornblende) present in felsic rocks (De Rita et al, 2011; Edmunds and Smedley 2013), and in some cases in ultramafic mafic rocks (Edgar et al., 1996), or the ion exchange between $\mathrm{Na}^{+}$or $\mathrm{Ca}^{2+}$ that occurs in clay minerals (Fig. 5b, c) such as illite, chlorite, smectite-type clays (Chang 1999; Chae et al., 2006; Glover et al. 2012; Houssein et al. 2017), which contain $\mathrm{F}$ in their structure (De Rita et al., 2011)

Some arid and semi-arid regions with alkaline thermal manifestations located in fluvial systems dominated by hyperalkaline felsic rocks (which accumulated $\mathrm{F}$ in melts and volatile fractions) and ash deposits have high $\mathrm{F}^{-}$contents in groundwater (Abu Rukah and Alsokhny, 2004; Edmunds and Smedley, 2013), several of these features are coincident with the characteristics of the study area, as the aquifer evolves hydrogeochemically, the pH becomes more alkaline (Fig. 5d).

The highest $\mathrm{F}^{-}$values were measured in water samples collected in the center of the basin (Fig. 1 and 3 ) corresponding to the $\mathrm{Na}^{-} \mathrm{HCO}{ }_{3}$ water type, in a geological environment sandwiched between lacustrine alluvial material (gravel-clay-sized granular) and fractured volcanic medium (Morales-Arredondo et al., $2020 \mathrm{a}$ and b). Ion exchange and silicate alteration affect the increase in $\mathrm{Na}^{+}$concentration as $\mathrm{F}^{-}$increases and $\mathrm{Ca}^{2+}$ decreases, towards the center of the basin in deep wells, as a result of silicate hydrolysis reactions, which explains the water enriched in $\mathrm{Na}^{+}$and $\mathrm{HCO}_{3}{ }^{-}$and depleted in $\mathrm{Ca}^{2+}$ and $\mathrm{Mg}^{2+}$ that together affect the increase in $\mathrm{F}^{-}$concentrations, even the devitrification of the matrix in the wells with thermal characteristics may be another factor affecting the increase in $\mathrm{F}^{-}$, since both parameters increase together (Fig. $5 \mathrm{a}, \mathrm{b}, \mathrm{c}, \mathrm{d}$ ), in fact this process could be dominant, since the results obtained indicate that $\mathrm{F}$ is disseminated in the volcanic glass and in some minerals of the volcanic rocks.

Another factor to consider is the mixing process that occurs between regional thermal waters that ascend through tectonic faults and interact with shallower groundwater (Morán-Ramírez, 2020), which influences the solubility, and reaction kinetics of some F-bearing minerals (Hem, 1985; Selinus 2005). For example Fluoride is mobilized to the environment through glass dissolution or devitrification processes (Johannesson and Tang, 2009; Savoie, 2013) because dissolution is relatively fast in reactive glass (Barranquero et al., 2017), Another process that occurs is related to the alteration of volcanic glass that causes an increase in pH (Appelo and Postma, 2005; Clark, 2015), and is involved in the alkaline desorption of some ions such as As and $\mathrm{F}^{-}$from mineral surfaces (Smedley and Kinniburgh, 2002) and in the dissolution of minerals containing competing anions that promote the mobilization of fluorides through anion exchange (Casentini et al., 2010; Xiao et al., 2017). This process is recurrent in clays (Yang et al., 2013). This behavior can be observed in the results obtained in the hydrogeochemical analysis, since it is evident that the $\mathrm{F}^{-}$content increases as the temperature of the medium increases as occurs in some aquifers where fluorite dissolution-precipitation is the hydrogeochemical control of F (with due exceptions) (Selinus, 2005).

Environmental risk related to elevated F- concentration in drinking water from 2010 to 2019. 
The results obtained since 2010 indicate that several wells present high F-contents (and in most cases in conjunction with high As contents) that exceed the maximum allowable limit according to NOM-127-SSA-Modified-2000 (F-=1.5 mg/L; As=0.025 mg/L) (Figure 6a) (Morales et al., 2015), in some wells the value is up to three times higher than what is allowed by the national drinking water regulations. This situation represents a health risk for the population.

\section{Survey on drinking water use in the study area.}

A survey was conducted in 2013 to learn about consumption patterns in JR communities (317 surveys) (157 males, 160 females) (Morales-Arredondo et al., $2018 \mathrm{a}$ and $\mathrm{b}$ ), The groups were represented by children aged 1 to 10 years (74); adolescents aged 11 to 15 years (25); youth aged 16 to 25 years (65); adults aged 26 to 50 years (111) and people older than 51 years (40). The population surveyed in Vill in 2017 was 184 people ( 94 females and 90 males). The groups were represented by adolescents aged 11 to 15 years (52) and adults aged 26 to 50 years (132), all participants were asked their place of residence, whether they drank tap water and whether they prepared food with tap water, older family members responded for the children surveyed. That survey indicated that of the 317 people surveyed, children and teenagers (aged 0.5 to 19 years) are at risk of exposure to fluoride as the calculated EFE value exceeds the level of $0.05 \mathrm{mg} / \mathrm{kg} /$ day, mainly in Cerro Gordo, Valencia, Guadalupe and Dulces Nombres, representing a potential risk of developing dental fluorosis, in the cases of Cerro Gordo and Valencia, the calculated EFE value exceeds the level of $0.12 \mathrm{mg} / \mathrm{kg} /$ day, mainly in children under 11 years of age, which means that this population is at potential risk of developing developing dental fluorosis and in some cases skeletal fluorosis, which is consistent with what has been observed in other studies reporting that children and the elderly are more vulnerable to developing dental fluorosis (Soto-Rojas et al, 2004; Betancourt-Lineares et al.,2013). However, that survey did not have actual data on the body mass of the population, their daily water intake and their length of residence in that community, so the results obtained from the EFE were calculated with standard values of body mass and water consumption by age ranges (Environment Canada, 1993; Ortíz et al., 1998). Considering that the lack of information of body mass, daily intake, and time of living in the community could result on a lower representativeness, a second survey was conducted in 2017 in the community Praderas de la Venta to know such information (Table 3 ), this community was selected because the well that supplies drinking water has a $\mathrm{F}^{-}$concentration of $7.1 \mathrm{mg} / \mathrm{L}$, another fact to consider is that a large part of the surveyed population does not live in Praderas de la Venta, but in Villagrán, where the drinking water well has a maximum $\mathrm{F}^{-}$concentration of $0.71 \mathrm{mg} / \mathrm{L}$.

Table 3

Summary of the survey of teenagers and adults in the community of Praderas de la Venta considering the age of the interviewees, their exposure time, the amount of water they drink daily and their weight.

\begin{tabular}{|c|c|c|c|c|c|c|c|c|c|c|c|c|}
\hline & \multicolumn{4}{|c|}{ Pradera de la Venta (teenagers) } & \multicolumn{4}{|c|}{ Villagrán (teenagers) } & \multicolumn{4}{|c|}{ Pradera de la Venta (adults) } \\
\hline & $\begin{array}{l}\text { Age } \\
\text { (years) }\end{array}$ & $\begin{array}{l}\text { Exposure } \\
\text { time (years) }\end{array}$ & L/day & $\begin{array}{l}\text { Weight } \\
(\mathrm{kg})\end{array}$ & $\begin{array}{l}\text { Age } \\
\text { (years) }\end{array}$ & $\begin{array}{l}\text { Exposure } \\
\text { time (years) }\end{array}$ & L/day & $\begin{array}{l}\text { Weight } \\
\text { (kg) }\end{array}$ & $\begin{array}{l}\text { Age } \\
\text { (years) }\end{array}$ & $\begin{array}{l}\text { Exposure } \\
\text { time (years) }\end{array}$ & L/day & $\begin{array}{l}\text { Weight } \\
\text { (kg) }\end{array}$ \\
\hline average & 12.8 & 8.7 & 1.9 & 50.0 & 12.9 & 12.9 & 1.7 & 47.1 & 35.2 & 14.9 & 1.7 & 75.9 \\
\hline minimum & 11.0 & 1.0 & 0.5 & 29.0 & 11.0 & 11.0 & 0.5 & 32.0 & 17.0 & 1.0 & 0.5 & 45.0 \\
\hline maximum & 15.0 & 15.0 & 5.0 & 83.0 & 15.0 & 15.0 & 3.0 & 77.0 & 64.0 & 42.0 & 3.0 & 118.0 \\
\hline $\begin{array}{l}\text { Standar } \\
\text { desviation }\end{array}$ & 0.8 & 3.5 & 0.9 & 11.9 & 0.8 & 0.8 & 0.8 & 11.0 & 10.1 & 12.4 & 0.6 & 15.3 \\
\hline $\mathrm{n}$ & 90 & 90 & 90 & 90 & 42 & 42 & 42 & 42 & 52 & 52 & 52 & 52 \\
\hline
\end{tabular}

A second interview campaign was then conducted in the town of Praderas de la Venta, with a population of 1420 people, where 184 surveys face to face were carried out to determine the consumption and weight of the people interviewed. The majority of the surveyed population informed that they do not drink tap water directly, but $88 \%$ prepare food and use this water for the rest of their needs In addition, the abstracted water does not receive any treatment for potabilization, and the water used for direct consumption is bottled by local companies only in the areas where the largest population is concentrated using treatment methods certified by the State Health Secretariat. However, water consumption also involves food preparation; and according to the survey results, a significant percentage of individuals prepare food with tap water in both municipalities.

Figure 6

\section{Fluoride Exposure Risk Estimation}

The results obtained from the survey were used to perform a fluoride exposure analysis; for this purpose, the intake thresholds for the toxic effects of a substance when an individual is subjected to chronic oral exposure suggested by ATSDR (ATSDR, 2016) were considered. The results obtained from well monitoring indicate that the population has been chronically exposed (more than one year) (Table 3), so the intake thresholds correspond to oral Reference Dose (RfD) conditions, where the order of magnitude is an estimate of the daily exposure that an individual can have to a toxic substance throughout his/her entire existence without presenting damage to any organ, the maximum intake of a toxicant that a human being can have without adverse clinical manifestations (NOAEL= No Observed Adverse Effect Level), and the minimum intake of the toxicant that causes adverse clinical manifestations in the exposed individual (LOAEL= Lowest-Observed-Adverse-Effect Level). The ATSDR (ATSDR, 2003) considers a NOAEL value of $0.15 \mathrm{mg}$ fluoride/kg/day and a LOAEL value of $0.25 \mathrm{mg}$ fluoride/ $\mathrm{kg} /$ day to observe skeletal effects (increased fractures); in the case of the NOAEL, it is divided by an uncertainty factor of three, to consider the variability in humans, and thus a value of RfD $=0.05$ (mg/ $/ \mathrm{kg} / \mathrm{day}$ ) is obtained. EPA (2003) derived an RfD of $0.06 \mathrm{mg} / \mathrm{kg} / \mathrm{day}$ for fluoride based on a NOAEL value of $0.06 \mathrm{mg} / \mathrm{kg} / \mathrm{day}$ and a LOAEL value of $0.12 \mathrm{mg} / \mathrm{kg} / \mathrm{day}$ for cosmetic effects of dental fluorosis. The NOAEL value was divided by an uncertainty factor of 1 to obtain the RfD. For this work, the following RfD values $=0.05 \mathrm{mg} / \mathrm{kg} / \mathrm{day}$ and $0.12 \mathrm{mg} / \mathrm{kg} / \mathrm{day}$ were considered as values at which effects can be observed. From the above values, if a value of FRE $>0.05$ ( $\mathrm{mg} / \mathrm{kg} / \mathrm{day})$ is obtained, exposed individuals may develop dental fluorosis, depending on the magnitude, dose and time of exposure. This value signifies the minimum risk level calculated by ATSDR (ATSDR, 2003; ATSDR, 2016) for chronic oral 
exposure and is considered the toxic threshold causing the occurrence of dental fluorosis. In case the value obtained is EEF $>0.12$ ( $\mathrm{mg} / \mathrm{kg} / \mathrm{day}$ ) and the exposure time is much longer than 15 years, the individual presents a potential risk of developing skeletal fluorosis (ATSDR,2003; ATSDR, 2016;).

Table 3

The results suggest that adolescents living in the municipal seat of Villagrán are not at risk of exposure to fluorides, however all people living in Praderas de la Venta are at risk of developing dental fluorosis, mainly adolescents who may also be at risk of developing skeletal fluorosis over time; for adults older than 20 years and who have lived in the area for more than 15 years, the results indicate that they are at risk of exposure to develop skeletal fluorosis (Figure $6 \mathrm{~b}$ ).

Considering the consumption patterns, part of the population studied is at risk due to the high fluoride content in drinking water for several years (at least since 2010) and its use for cooking by a significant amount of the population, the greatest risk is the locality of Praderas de la Venta. It would be convenient to carry out an epidemiological study in the area to determine the possible fluoride accumulation due to consumption of poor-quality water, looking for cases of dental or skeletal fluorosis.)

\section{Conclusions}

Fluoride contamination in groundwater is a major problem in drinking water sources in the study area as high $\mathrm{F}^{-}$content has been quantified in drinking water in several wells since 2010; however, the water contamination problem in the region dates back to the 1990s. Aquifers composed of rhyolites and ignimbrites present high fluoride levels that exceed WHO and NOM-127 guidelines, results from the present and previous studies conducted in the area indicate that the origin is natural, according to mineralogical, hydrogeochemical and statistical results, the behavior of excess fluoride is related to the interaction between geothermal groundwater and volcanic rocks and the depth of fluids enriched in $\mathrm{F}^{-}$. Fluoride is disseminated in volcanic rocks and the highest contents were measured in felsic rocks. Hierarchical clustering evidenced a correlation between tridymite with As and $\mathrm{F}$ and alunite. Relationship between the minerals sanidine and andesine, minerals commonly found in felsic rocks were also shown by the clustering another cluster marks a bifurcation between esseneite (common in mafic rocks) and other component minerals of volcanic rocks, but a closer relationship with Felspar Na-Ca, Monoalbite and Kaolinite, recurrent minerals in intermediate rocks, also a correlation was observed between amorphous silicate tuff with two groups of minerals, one is quartz with plagiocase albite and the other composed of kaolinite-montmorillonite with cristobalite. Fluoride mobilization is a product of volcanic glass dissolution, a process involved in alkaline desorption occurring on the surfaces of $\mathrm{F}^{-}$containing minerals, and possibly by ion exchange occurring in minerals and some clays or even in deep fluids enriched in $\mathrm{F}^{-}$. Low $\mathrm{Ca}^{2} \rrbracket$ and elevated bicarbonate $\left(\mathrm{HCO}_{3}{ }^{-}\right)$and sodium $(\mathrm{Na} \rrbracket)$ concentrations in high- $\mathrm{F}$ groundwater suggest hydrogeochemical regulation involving these ions.. All these processes may be accelerated by the geothermal characteristics of the groundwater in the study area. The information from this study can be used to identify hydrogeochemical processes related to fluoride mobilization and transport in the aquifer, as these results have helped to define the rock type contributing to the high fluoride content in groundwater. The hydrogeochemical results and the epidemiological survey conducted indicate that the population of Praderas de la Venta is at risk of exposure to F-due to the high concentrations ingested over a long period of time, the toxicity of the element and its ability to accumulate in the bones. As has been observed in other areas with similar problems, he most vulnerable people are children and older adults according to the results of this study.

\section{Bibliografia}

Abu Rukah Y, Alsokhny K. 2004. Geochemical assessment of groundwater contamination with special emphasis on fluoride concentration, North Jordan. Chemie der Erde - Geochemistry, 64(2): 171-181.

Apelo CAJ, Postma D. 2005. Geochemistry, Groundwater and Pollution (2nd ed., pp. 137-142). Amsterdam A.A. Balkema Publishers.

Armienta MA, Segovia N. 2008. Arsenic and luoride in the groundwater of Mexico. Environ. Geochem. Health 30. 345-352. https://doi.org/10.1007/s10653008-9167-8

Armienta MA, Rodríguez R, Segovia N, Montiel M. 2010. Medical Geology in Mexico, Central America and theCaribbean, O. Selinus et al. (eds.), Medical Geology, International Year of Planet Earth, in Springer Science+Business Media B.V. p 59 - 78

APHA-AWWA and WWF. 2005. Standard methods for the Examination of Water and Wastewater. American Public health Association, the American Water Works Association, Association Water Environment Federation, Washington, D. C.

Aguillón-Robles A, Aranda-Gómez JJ, Solorio-Munguía JG. 1994. Geología y tectónica de un conjunto de domos riolíticos del Oligoceno medio en el sur del Estado de San Luis Potosí, México: Universidad Nacional Autónoma de México, Instituto de Geología, Revista Mexicana de Ciencias Geológicas, $11,29-42$.

Aranda-Gómez JJ, McDowell F. 1998. Paleogene extension in the southern basin and range province of Mexico: syndepositional tilting of eocene red beds and oligocene volcanic rocks in the Guanajuato Mining District. Int Geol Rev 40:116-134

Arellano ARV, Pantoja J, Ledesma 0. 1960. Yacimientos de minerales no metálicos de la región de Nautla, Municipio de Comonfort, Guanajuato, Informe técnico Consejo de Recursos Naturales no Renovables, 39pp.

Agency for Toxic Substances and Disease Registry Agency for Toxic Substances and Disease Registry, (ATSDR), 2003. Toxicological profile for fluoride, hydrogen fluoride, and fluorine (F). Recovered from https://www.atsdr.cdc.gov/toxprofiles/tp11-c3.pdf 
Agency for Toxic Substances and Disease Registry, (ATSDR). 2016. Resúmenes de salud pública (fluoruros, fluoruros de hidrógeno, flúor). Recuperado de https://www.atsdr.cdc.gov/es/phs/es_phs11.html

Barranquero RS, Varni M, Vega M, Pardo R, Ruiz de Galarreta A. 2016. Arsenic, fluoride and other trace elements in the Argentina Pampean plain. Geologica Acta 15(3): 187-200 doi:10.1344/GeologicaActa2017.15.3.3

Betancourt-Lineares A, Irigoyen-Camacho ME, Mejía-González AM, Zepeda-Zepeda M, Sánchez-Pérez L. 2013. Prevalencia de fluorosis dental en localidades mexicanas ubicadas en 27 estados y el D.F. a seis años de la publicación de la Norma Oficial para la fluoruración de la sal. Rev Invest Clin 65(3): $237-247$.

Casentini B, Pettine M, Millero F. 2010. Release of Arsenic from Volcanic Rocks through Interactions with Inorganic Anions and Organic Ligands: Aquatic Geochemistry, v. 16, no. 3, p. 373-393. https://doi.org/10.1007/s10498-010-9090-3

Cerca-Martínez LM, Aguirre-Díaz GJ, López-Martínez M. 2000. The geologic evolution of the southern Sierra de Guanajuato, Mexico: a documented example of the transition from the Sierra Madre Occidental to the Mexican Volcanic Belt. Int Geol Rev 42:131-151. https://doi.org/10.1080/00206810009465073

Chae G, Yun S, Kwon M, Kim Y, Mayer B. 2006. Batch dissolution of granite and biotite in water: Implication for fluorine geochemistry in groundwater, Geochemical Journal, vol 40. Pp.95-102.

Chae GT, Yun ST, Mayer B, Kim KH, Kim SY, Kwon JS, Kim K, Kohn YK. 2007. Fluorine geochemistry in bedrock groundwater of South Korea. Sci., Total Environ. Pp 272-283.

Chang R. 1999. Química General, séptima edición McGraw-Hill, México pp 1-943.

Christiansen EH, Sheridan MF, Burt DM. 1986. The geology and geochemistry of Cenozoic topaz-rhyolites from western United States: Geological Society of America Special Paper 205, 82 p.

Chiba J Kusumoto M, Shirai S, Ikawa K, Sakamoto S. 2002. "The influence of fluoride ingestion on urinary aluminum excretion in humans". Tohoku J. ExpMed. 2002 Mar, 196(3): 139-149.

Clark I. 2015. Groundwater Geochemistry and Isotopes. CRC Press. 456 pp. https://doi.org/10.1201/b18347

Consejo Nacional de Evaluación de la Política de Desarrollo Social (CONEVAL). 2018a. Informe de evaluación de la política de desarrollo social. Resumen ejecutivo 60pp. https://www.coneval.org.mx/Evaluacion/IEPSM/IEPSM/Documents/RESUMEN_EJECUTIVO_IEPDS2018.pdf

Consejo Nacional de Evaluación de la Política de Desarrollo Social (CONEVAL). 2018b. Informe Anual sobre la situación de pobreza y rezago social. Santa Cruz de Juventino Rosas y Villagrán https://www.gob.mx/cms/uploads/attachment/file/44749/Guanajuato_035.pdf https://www.gob.mx/cms/uploads/attachment/file/44749/Guanajuato_044.pdf

Dahlkamp FJ. 2010. Uranium deposits of the world. USA and LatinoAmerica editor. Springer, Berlin

De Rita D, Cremisini C, Cinnirella A, Spaziani F. 2011. Fluorine in the rocks and sediments of volcanic áreas in central Italy: total content, enrichement and leaching processes and hypothesis on the vulnerability of the related aquifers. Environ. Monit. Assess. Pp. 5781-5796

del Río-Varela P, Nieto-Samaniego AF, Alaniz-Álvarez SA, Ángeles-Moreno E, Escalona-Alcázar FJ, del Pilar-Martínez A. 2020. Geología y estructura de las sierras de Guanajuato y Codornices, Mesa Central, México. Bol. Soc. Geol. Mex vol.72 no.1. https://doi.org/10.18268/bsgm2020v72n1a071019

Deng Y, Nordstrom DK, McCleskey RB. 2011. Fluoride geochemistry of thermal waters in Yellowstone National Park: I Aqueous fluoride speciation. Geochemica Et Cosmochimica Acta 75:4476-4489.

Edgar AD, Pizzolato LA, Sheen J. 1996. Fluorine in igneous rocks and minerals with emphasis on ultrapotassic mafic and ultramafic magmasand ultramafic magmas and their mantle source regions. Min. Mag., v. 60 - 399:243-257.

Edmunds WM, Smedley PL. 2013. Chapter 12: Fluoride in natural waters. In: Essentials of Medical Geology, Second Edition. Eds: Selinus, O., Alloway, B., Centeno, J.A., Finkelman, R.B., Fuge, R., Lindh, U. and Smedley, P.L. Springer, 311-336.

Environment Canada. 1993. Canadian environmental protection act priority substances list assessment report: Arsenic and its compounds. Ottawa, Canada: Canada Communication Group.

Flanagan FJ. 1976. 1972 Compilation of data on USGS standards. En Descriptions and Analyses of Eight New USGS Rock Standards. Geological Survey Professional Paper 840. United States Government Printing Office, Washington, D.C., United States. pp. 131-171.

Gi-Tak C, Seong-Taek Y, Man-Jae Y, Yi-Seop K, Berbhard M. 2006. Batch dissolution of granite and biotite in water: Implication for fluorine geochemistry in groundwater, Geochemical Journal, vol 40. Pp.95-102.

Glover ET, Akiti TT, Osae S. 2012. Major ion chemistry and identification of hydrogeochemical processes of groundwaterr in the Accra Plains. Elixir Geoscience, $50,10279-10288$ 
Guo Q, Wang Y, Ma T, Ma R. 2007. Geochemical processes controlling the elevated fluoride concentrations in groundwater of the Taiyuan Basin, Northern China. Journal of Geochemical Exploration, 93(1): 1-12.

Houssein AA, Elmi RW, Zghibi A, Ouddane B. 2017. Assessment of chemical quality of groundwater in coastal volcano-sedimentary aquifer of Djibouti, Horn Africa. Journal of African Earht Sciences, 131: 284-300

Instituto de Ecología del Estado de Guanajuato (IEEG). 2008. Informe Ambiental del Estado de Guanajuato. Informe.

Instituto Nacional de Estadística y Geografía (INEGI). 2017. Anuario Estadístico y Geográfico de Guanajuato

http://www.datatur.sectur.gob.mx/ITxEF_Docs/GTO_ANUARIO_PDF.pdf

Jochum K P, Weis U, Schwager B, Stoll B, Wilson SA, Haug GH, Andreae MO, Enzweiler J. 2015. Reference Values Following ISO Guidelines for Frequently Requested Rock Reference Materials. GEOSTANDARDS And GEOANALYTICAL RESEARCH. 40 (3). pp. 333-350.

Jiménez-Zabala A, Santa-Marina L, Otazua M, Ayerdi M, Galarza A, Gallastegi M, Ulibarrena E, Molinuevo A, Anabitarte A, Ibarluzea. 2017. Fluoride intake through consumption of water from municipal network in the INMA-Gipuzkoa cohort. Gac Sanit 32(5): 418-427

https://dx.doi.org/10.1016/j.gaceta.2017.02.008

Johannesson KH, Tang J. 2009. Conservative behavior of arsenic and other oxyanion-forming trace elements in an oxic groundwater flow system. Journal of Hydrology. 378(1-2):13-28 doi:10.1016/j.jhydrol.2009.09.003

Juárez-Aparicio F. 2019. Evaluación de rocas calizas del Bajío Guanajuatense en la remoción de arsénico y fluoruro en el agua subterránea. Tesis Maestría, UNAM, pp. 113 https://tesiunam.dgb.unam.mx/F/SAPN846LKFXKAB4BGADLGKTIP19PNMQXLVDRG74YXCAUYPQV7X-32942?func=full-setset\&set_number $=594460 \&$ set_entry=000001\&format $=999$

Li L. 2003. The biochemistry and physiology of metallic fluoride: action, mechanism, and implications. Crit. Rev. Oral Biol. Med.14(2): 100-114

Liu M, Qian C. 2008. Effect of endemic fluorosis on children's intelligence development: a Meta-analysis. (in Chinese). Zhongguo Dang Dai Er Ke Za Zhi 10(6): $723-725$

Nava AJ, Serna VR. 1958. Yacimiento de alunitas en la región de Romero, Guanajuato. Informe técnico del Consejo de Recursos Naturales y No renovables, Departamento de Exploración, 22 pp.

Nicolli HB, Tineo A, García JW, Falcón CM, Smedley PL. 2012. Mobilization of arsenic and other trace element of health concern in groundwater from the Salí River Basin,Tucumán Province, Argentina. Environ Geochem Health;34(2):251-62.

Nieto-Samaniego AF, Ojeda-García AC, Alaniz-Álvarez SA, Xu SS. 2012. Geología de la región de Salamanca, Guanajuato, México. Bol Soc Geol Mex 62(3):411-425. http://www.scielo.org.mx/scielo.php?pid=S1405-33222012000300010\&script=sci_abstract

NOM-127-SSA1-1994-2000. 2000. Norma Oficial Mexicana "Salud ambiental, agua para uso y consumo humano-límites permisibles de calidad y tratamientos a que debe someterse el aguapara su potabilización”. México D.F. http://www.dof.gob.mx/nota_detalle.php?codigo=2063863\&fecha=22/11/2000

NOM-230-SSA1-2002. 2002. Norma Oficial Mexicana, Salud ambiental. Agua para uso y consumo humano, requisitos sanitarios que se deben cumplir en los sistemas de abastecimiento públicos y privados durante el manejo del agua. Procedimientos sanitarios para el muestreo in.

http://www.salud.gob.mx/unidades/cdi/nom/230ss a102.html

Morales-Arredondo JI, Villanueva-Estrada RE, Rodríguez R, Armienta MA. 2015. Geological, hydrogeological, and geothermal factors associated to the origin of arsenic, fluoride, and groundwater temperature in a volcanic environment “El Bajío Guanajuatense”, Mexico. Environmental Earth Sciences. 74:6; 5403-5415.

Morales-Arredondo JI, Esteller-Alberich MV, Armienta Hernández MA, Martínez-Florentino TAK. 2018a. Characterizing the hydrogeochemistry of two lowtemperature thermal systems in Central Mexico, Journal of Geochemical Exploration; 185, 93-104.

Morales Arredondo JI, Armienta Hernández MA, Rodríguez Castillo R. 2018b. Estimación de la exposición a elevados contenidos de fluoruro en agua potable en distintas comunidades de Guanajuato México. TECNOLOGIA Y CIENCIAS DEL AGUA; IX (3).

Morales-Arredondo JI, Armienta-Hernández MA, Ortega-Gutiérrez JE, Flores-Ocampo IZ, Flores-Vargas R. 2020. Evaluation of the CO2 behavior in a termal aquifer located at Central Mexico and its relation to silicate weathering. International Journal of Environmental Science and Technology 17(7), 3411-3430 DOI: $10.1007 / \mathrm{s} 13762-020-02683-3$

Morales-Arredondo JI, Flores-Ocampo IZ, Armienta Hernández MA, Moran-Ramírez J, Hernández-Hernández MA, Landa-Arreguin JF. 2020. Identificación de las fuentes de nitratos mediante métodos hidrogeoquímicos e isotópicos en el agua subterránea del Bajío Guanajuatense. Geofísica Internacional, 59:3 169-194. ISSN 0016-7169. https://doi.org/10.22201/igeof.00167169p.2020.59.3.2093.

Moran-Ramírez J, Morales-Arredondo Jl, Armienta Hernández MA, Ramos-Leal JA. 2020. Quantification of the mixture of hydrothermal and fresh water in tectonic valleys. Journal of Earth Science (aceptado) https://doi.org/10.1007/s12583-020-1294-x 
Onipe T, Edokpayi NJ, Odiyo JO. 2020. A review on the potential sources and health implications of fluoride in groundwater of Sub-Saharan Africa, Journal of Environmental Science and Health, Part A, DOI: 10.1080/10934529.2020.1770516

Ortíz D, Castro L, Turrubiates F, Milan J, Díaz-Barriga F. 1998. Assessment of the exposure to fluoride in drinking water from Durango, Mexico, using a Geographic Information System. Fluoride,31(4), 183-187.

Rocha-Amador D, Navarro EM, Carrizales L, Morales R, Calderon J. 2007. Decreased intelligence in children and exposure to fluoride and arsenic in drinking water. Cad. Saúde Pública 23(4):579-587. https://doi.org/10.1590/S0102-311X2007001600018

Rodríguez RC, Rodríguez-Velázquez I. 2006. Consecuencias sociales de un desastre inducido, subsidencia. Boletín de la Sociedad Geológica Mexicana 63(2): 265-269.

Rodríguez R, Schroeder A. 2010. Structural control on the subsidence faults alignment in Irapuato Mexico. Aquamundi, Italy. Vol 1, Num 1, 45-49 pp.

Rodríguez R, Morales I, Armienta A, Villanueva R, Segovia N. 2015. Geothermal Systems of Low Temperature in Mexican Highlands: Alternative Uses and Associated Risks. Procedia Environmental Sciences. 25; 214-219.

Savoie, C B Y. 2013. Arsenic Mobility and Compositional Variability in High-Silica Ash Flow Tuffs. Dissertations and Theses. Paper 1012. https://pdxscholar.library.pdx.edu/open_access_etds/1012/ DOI: 10.15760/etd.1012

Saxena VK, Ahmed S. 2001. dissolution of fluoride in groundwater: a water-rock interaction study, Environmental Geochemistry and Health - Springer, pp. 1084- 1087

Schoeder A. 2010. Análisis de la formación de fallamiento por subsidencia en la zona de Irapuato Gto. Tesis Maestría. UNAM.

Selinus 0. 2005. Essentials of medical geology. Impacts of the natural environment on public health. Elsevier Academic Press. 826 pp. ISBN: 9780126363418

Shimizu K, Itai T, Kusakabe M. 2006. Ion chromato-graphic determination of fluorine and chlorine in silicaterocks following alkaline fusion. Geostand.

Geoanal. Res.30, 121-129

Stewart C, Damby DE, Tomašek I, Horwell CJ, Armienta MA, Ruiz-Hinojosa MG, Appleby M, Delmelle P, Cronin S, Ottley CJ, Oppenheimer C, Morman S. 2020. Assessment of leachable elements in volcanic ashfall: A review and evaluation of a standardized protocol for ash hazard characterization, Journal of Volcanology and Geothermal Research, 392:106756, https://doi.org/10.1016/j.jvolgeores.2019.106756.

Smedley PL, Nicolli HB, Macdonald DMJ, Barros AJ, Tullio JO. 2002. Hydrogeochemistry of arsenic and other inorganic constituents in groundwaters from La Pampa, Argentina. Appl. Geochem. 17, 259-284.

Sung J. 2011. Geochemical occurrences of arsenic and fluoride in bedrock groundwater: a case study in Geumsan County, Korea., Environ. Geochem. Health. Pp 43-55

Strunecká A, Patočka J. 2002. Aluminofluoride complexes: a useful tool in laboratory investigations, but a hidden danger for living organisms? In: Fundamental Research, Material

Tang QQ, Du J, Ma HH, Jiang SJ, Zhou XJ. 2008. Fluoride and children's intelligence: a meta-analysis. Biol Trace Elem Res126 (1-3): 115-20.

Verma MP, Izquierdo G, Urbino GA, Gangloff S, García R, Aparicio A, Conte T, Armienta MA, Sánchez M, Gabriel JRP, Fajanela ID, Renderos R, Acha CBA, Prasetio R, Grajales IC, Reyes-Delgado L, Opondo K, Zendejas-Esparza R, Panama LA, Tapia-Salazar R, Lim PG, Javino F. 2012. Inter-laboratory comparison of SiO 2 analysis for geotermal wáter chemistry, Geothermics. 44: 33-42 https://doi.org/10.1016/j.geothermics.2012.06.003

USEPA (U.S. Environmental Protection Agency). 2010. Fluoride: Exposure and Relative Source Contribution Analysis. Office of Water, Washington, DC. EPA 820R-10-015.

USEPA (U.S. Environmental Protection Agency). 1992a. Guidelines for exposure assessment. U.S. Environmental Protection Agency. Fed. Reg. 57:22888 22938. Washington D.C., USA, p.126. https://www.epa.gov/sites/production/files/2014-11/documents/guidelines_exp_assessment.pdf

Verma MP, Portugal E, Gangloff S, Armienta MA, Chandrasekharam D, Sanchez M, Renderos RE, Juanco M, van Geldern R. 2015. Determination of carbonic species concentration in natural waters - Results from a worldwide proficiency test. - Geostandards and Geoanalytical Research, 39:233-255,

https://doi.org/10.1111/j.1751-908X.2014.00306.x

Xiao T, Dai Z, Viswanathan H, Hakala A, Cather M, Jia W, Zhang Y, McPherson B. 2017. Arsenic mobilization in shallow aquifers due to CO2 and brine intrusion from storage reservoirs, Scientific Reports 7(2763) https://doi.org/10.1038/s41598-017-02849-z

Zhang B, Hong M, Zhao, Lin X, Zhang X, Dong J. 2003. Distribution and risk assessment of fluoride in drinking water in the western plain region of jilin province, China. Environ Geochem Health, 25: 421-31.

Zhang L, Li Q, Ma L, Ruan J. 2013. Characterization of Fluoride Uptake by Roots of tea Plants (Camellia Sinensis (L.) 0. Kuntze). Plant Soil 366 (1), $659-669$. doi:10.1007/s11104-012-1466-2

Page 13/18 
Figures
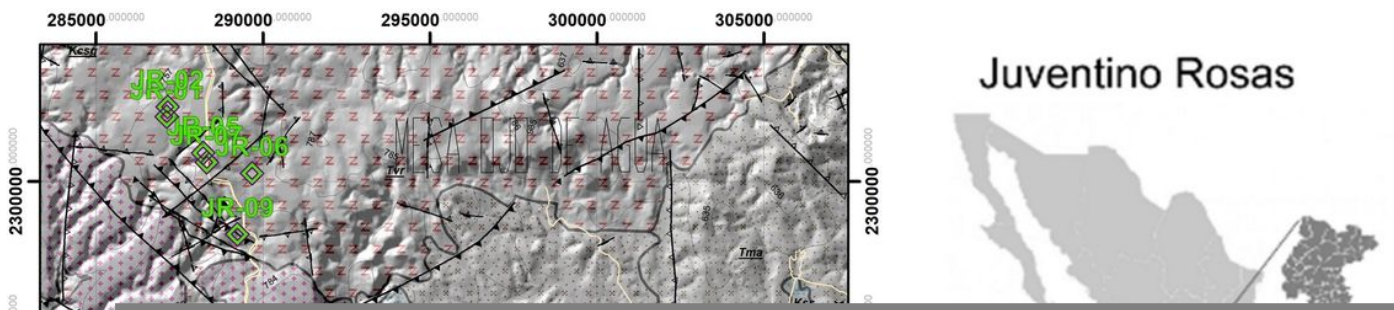

\section{Figure 1}

Study area, State of Guanajuato and municipalities of Santa Cruz de Juventino Rosas and Villagrán considering the local geology. Location of the communities. 
S J Mer

\begin{tabular}{|lll|}
\hline Well & $\square^{\text {Qal Alluvial deposit }}$ & $\square_{\text {Tithological section }}^{\text {Tvr Rhyolite }}$ \\
\hline Fss Soyatal & $\square_{\text {Formation }}^{\text {Tmb Basaltic plateau }}$ & $\square^{\text {Normal fault }}$ \\
\hline
\end{tabular}

A

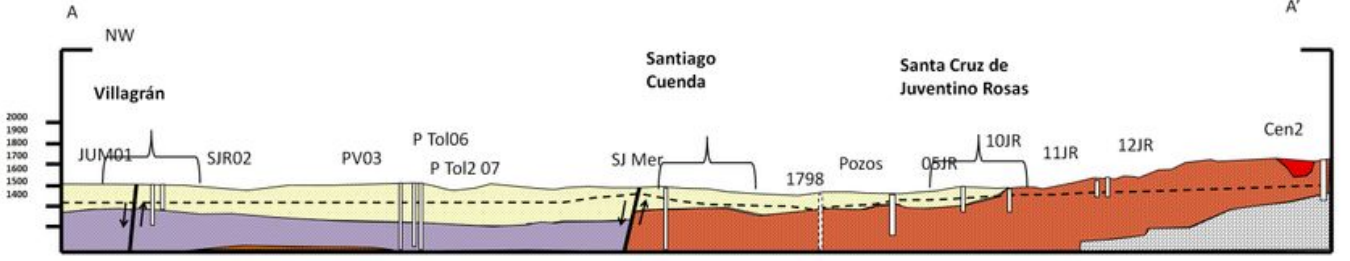

C

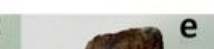

\section{Figure 2}

AA' stratigraphic profile of the study area where two lithological sections of the SJ Mer= San José Merino and 1798 wells are presented, and some rock samples collected in the study zone: (a) tholeiitic basalt, (b) vitreous tuff, (c) lepidolitic vitreous tuff, (d) altered vitreous tuff, (e) ignimbrite, and (f) ignimbrite. Photomicrographs under parallel light: $(g)$ basalt: pyroxene microphenocrysts (Px) replaced with opaque minerals; (h) vitreous tuff: lithic fragments composed of a vitreous matrix within a Fe oxyhydroxide (Fe-ox M) matrix; (i) lepidolitic vitreous tuff: lithic fragments of perlitic glass disseminated throughout a vitreous matrix; $(j)$ altered vitreous tuff: matrix formed by a vitreous paste with some oxides and Fe-oxyhydroxides (Fe-ox), feldspars (Felds), and quartz (Qz); (k) ignimbrite: alignment of vitreous fragments forming the matrix, some veins obliquely cut across fiammes; (I) ignimbrite: vitreous matrix with quartz and clay mineral veins that replace feldspars, biotites moderately replaced by chlorite. Photomicrographs under reflected light: ( $\mathrm{m}$ ) basalt: to the left, hematite has been replaced by goethite/siltstone and, to the right, dispersed magnetite can be observed; (n) vitreous tuff: lithic fragments surrounded by goethite/siltstone and some hematite crystals along their edges in addition to some pyrite relicts completely replaced by magnetite; (o) lithic tuff: a completely hematized particle with abundant oxides and Fe-oxyhydroxides at its edges; $(p)$ altered vitreous tuff: a completely hematized particle in the upper portion of the image, pyrite, and galena in the lower portion; (q) ignimbrite: an elongated lens, thin in the direction of the fiammes, formed by hematite associated with goethite/siltstone; (r) ignimbrite: a fine crystal surrounded by hematite. 

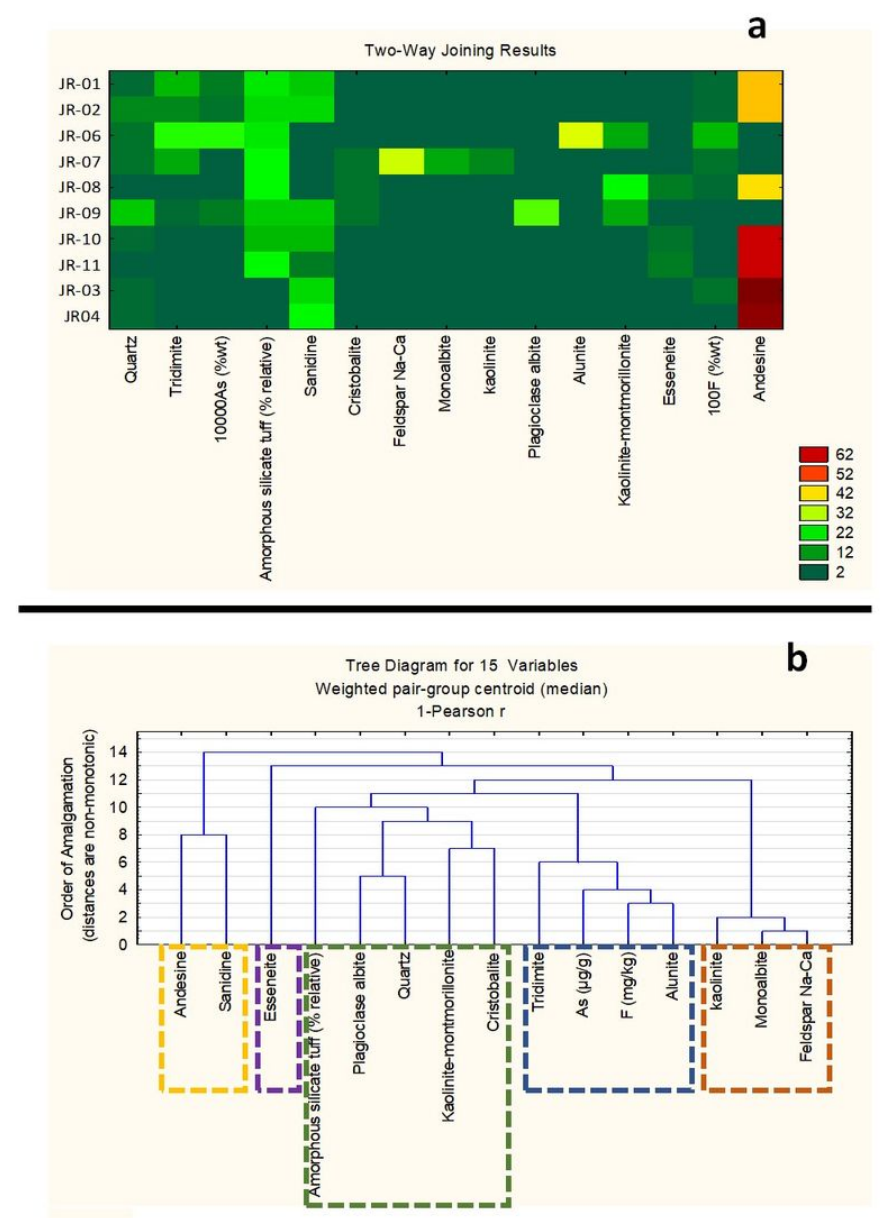

\section{Figure 3}

a) Composición mineralógica (en \%) de diferentes rocas presentes en la zona de estudio, Mineralogical composition (\%) of rocks present in the study area b) Hierarchical clustering (Weighted pair-group centroid (median), 1-Pearson r aglomeration algorithm) of mineralogy of volcanic rock and their As and $\mathrm{F}$ content.

\section{Figure 4}

Rock sample JR-03-2015 collected southwest of the study area near to the SJ Mer well to which a SEM-EMS analysis was performed to qualitatively identify the distribution of fluoride in the rock. 

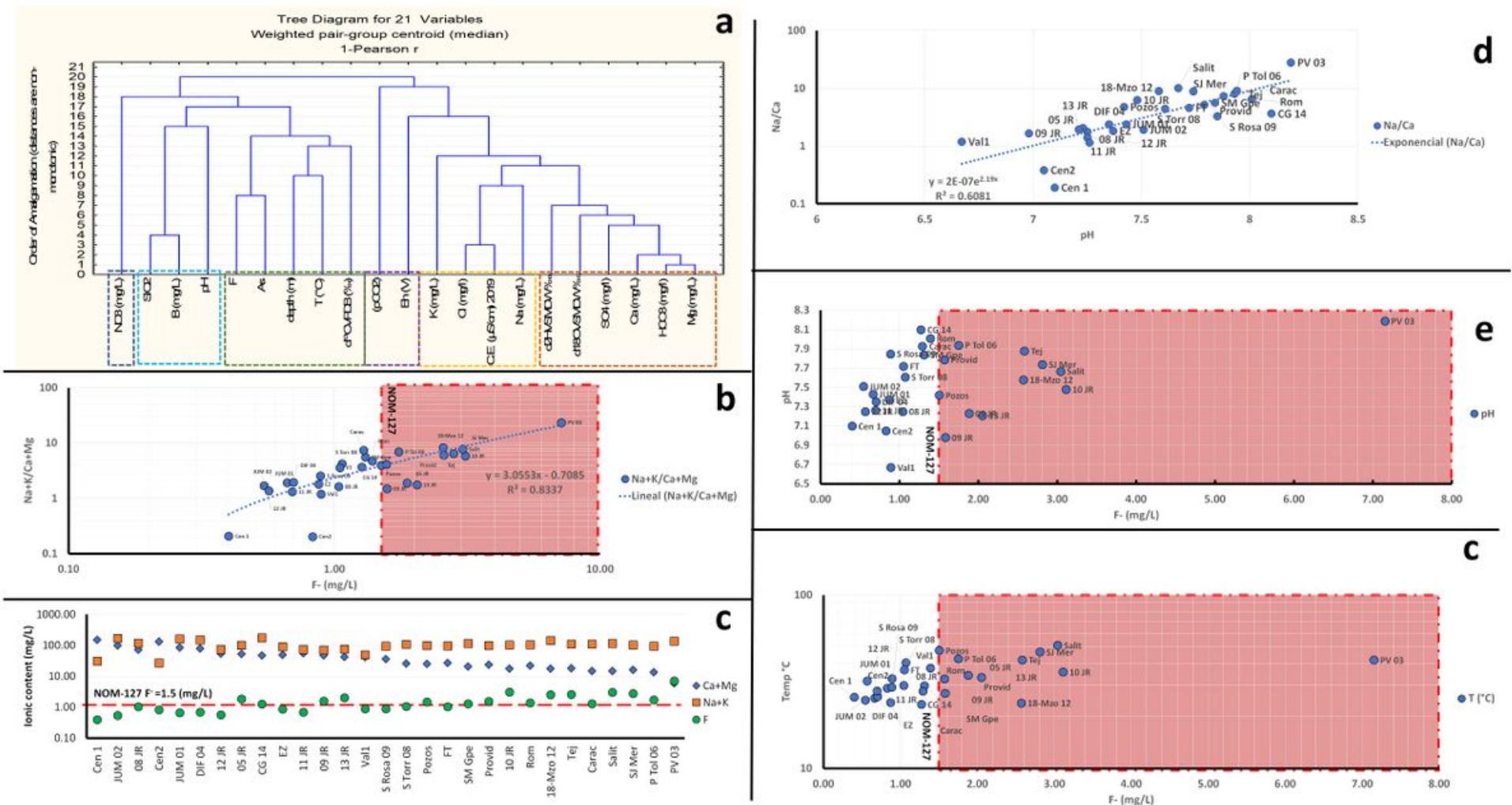

\section{Figure 5}

a) Hierarchical clustering (Weighted pair-group centroid (median), 1-Pearson r agglomeration algorithm) of physicochemical and isotopic results of groundwater samples from the study area, b) Comparison between $\mathrm{Na} / \mathrm{Ca}$ ratio vs F-concentration in groundwater from JR and Vill. The red line represents the maximum value allowed by NOM-127 for fluoride. 


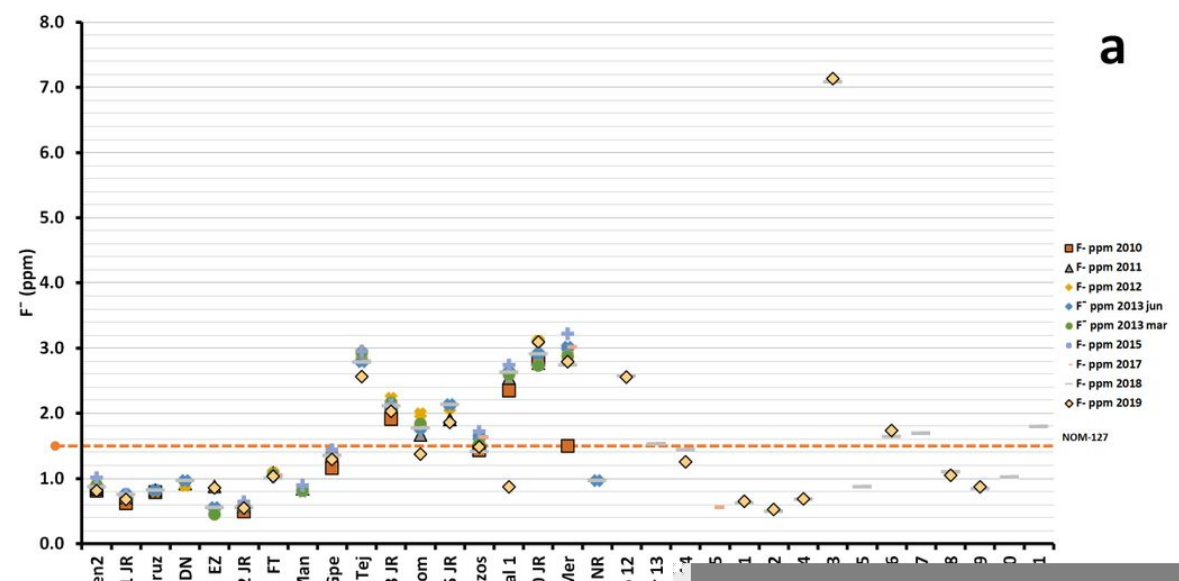

\section{Figure 6}

a) F- concentration (ppm) in the different wells sampled during the years 2010-2019, b) Comparative diagram of the EEF values (with parameters obtained in the locality) versus exposure time for each individual interviewed. Symbols in rhombus represent adolescents interviewed living in Praderas de la Venta, symbols in triangle represent adolescents interviewed living in the locality of Villagrán, symbols in circle represent adults interviewed living in Praderas de la Venta. The fields represent: 1) the population that has no risk of exposure to fluoride, 2) the population that is at risk of developing dental fluorosis, 3 ) the population that is at risk of developing dental fluorosis and has more than 5 years of exposure, 4) the population that is at risk of developing skeletal fluorosis, 5) the population that is at risk of developing skeletal fluorosis and has more than 5 years of exposure, 6 ) the population that is at risk of developing skeletal fluorosis and has more than 15 years of exposure. 